\section{V-25後方アプローチ後腹膜䶼鏡下堅、副督手術 一督夏胞開空と副腎腫瘏摘除一}

\section{東京女子医科大学 医学部 泌尿器科 1 )}

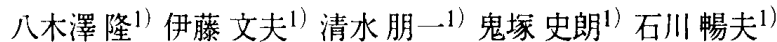
新村 浩明1) 合谷 (信行1) 天野裕之 ${ }^{1)}$ 東間 紘1)

[目的］後方アプローチ、後腹膜腔鏡下の操作による腎、副腎手 術を腎襄胞開空、副腎腫腸摘除を例に取り上げて供覧し、本法の 長所、短所などについて考察する。[手術手技] 全身麻酔下に完 全腹臥位とする。患側第 12 肋骨先端直下に1.5 $\mathrm{cm}$ の切開（第 1 ポ 一ト）を置き、後腹膜腔に到達する。拡張バルーンにより後腹膜 腔スペースを作成する。第 1 ポートの $2 \sim 3 \mathrm{~cm}$ 内外側に第 2 , 第 3 ポートを作成する。気腹後、肉眼、あるいは超音波により腎襄胞、 副腎腫瘍を確認する。腎囊胞では襄胞を十分に露出させたのち、 内容液を吸引し、Ultrasonically activated scalpel (UAS)によって衰胞壁 を切除する。副腎腫場ではGerota筋膜を腎上極部で切開した後、 副婜腫湯を検索し、腫瘍周囲の剥離を進める。剥離は腫瘍の上側、 外側から始めるが、この操作はCavitron ultrasonic surgical aspirator (CUSA)、Ultrasonically activated scalpel (UAS)、Clipを用いて行う。最 終的に副腎動静脈を切離し、腫瘍を遊離する。腫瘍を袋に収納し、 ポート創より摘出する。[結語] 本法はポート間が狭く、操作腔 が小さいという難点があるものの、CUSA、UASを用いることに より容易に腎、副腎を操作できる有用な方法である。

\section{後腹膜腔鏡下手術 督严胞 副腎腫痖}

\section{V-27吊り上げ法を用いた側方アプローチによる 後腹膜鏡下副腎摘出術}

\author{
福島県立医科大学 医学部 泌尿器科 ${ }^{1)}$

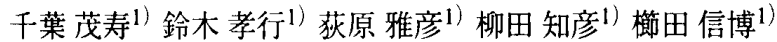 \\ 酒井多喜夫 ${ }^{1)}$ 山口偹) \\ 【目的】当科では、1993年に腹腔鏡下副腎摘出術を開始して以来、 \\ 1996、1997年にそれぞれ後腹膜鏡下操作、気腹を用いない吊り上 \\ げ法を操用してきた。今回演者らは、吊り上げ法を用いた側方了 \\ プローチによる後腹膜鏡下副腎摘出術につき、その術式と手術成 \\ 績を供覧する。【対象と方法】1998年9月〜1999年11月の間に当科 \\ で本術式により副堅摘出術を行った 9 例(年令34〜69才,腫瘍径2 \\ $5 \mathrm{~cm})$ を対象とした。患側は右 1 例、左 8 例であり、原疾患はプレク \\ ッシング症候群㧍よび非機能性腫瘍3例、クッシング症候群2例、 \\ 原発性アルドステロン症 1 例であった。な㧍、うち2例が中等度 \\ 以上の肥渵、3例が呼吸器障害を有していた。側卧位とし、腸骨 \\ 稜上縁、第12肋骨下縁、前腋下線2ケ所に計4本のポートを留置、 \\ 第12肋骨下縁でLaparolift ${ }^{\mathrm{TM}}$ により吊り上げを行った。USU'Mを用い \\ て腎臓前側面を展開しながら、副腎を同定剥離した。副腎静脈に \\ クリップをかけ切断した後、副腎を一塊として体外に取り出した。 \\ 【結果】全例で副腎摘出が可能であり、平均手術時間および出血 \\ 量は140分、135mlであった。術後合併症として、1例にのみ無気肺 \\ がみられたものの、その他術中、術後経過は極めて良好であった。 \\ 【結語】本術式は高度肥満や呼吸器合併症を有する患者に対して \\ も、安全かつ確実に施行叮能と考えられた。
}

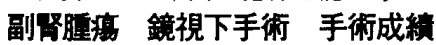

\section{V- 26 腹腔鏡下副掔摘除における到達法の選択}

\author{
東北大学 医学部 泌尿器科 ${ }^{1}$ \\ 千葉 裕 $^{1 ）}$ 佐藤 (信 $^{1}$ 庵谷尚正 ${ }^{1}$ 渡部隆二1）伊藤 明宏 1 ) \\ 折笠精一1)
}

腹腔鏡下副腎摘除の到達法として現在当科では，後腹膜後方到達 法と経腹膜前方到達法を症例ごとに選択している。右副腎摘除の 場合は全摘・部分切除に関係なく，後腹膜後方到達法を第一選択 としている。その最大の理由は肝・下大静脈の在排が不要で, 経 腹膜到達法よりむしろ安全かつ容易な手術が行い得る点にある。 一方，左副腎摘除の場合には，左副腎尾側部分の処理が左腎上極 が邪魔になり困難な症例が多いため経腹膜到達法を選択すること が多い。しかし，手術侵襲はやはり後腹膜到達法の方が少なく， 術前のCTやMRIで左副腎の位置が左腎上極より明らかに頭側にあ る症例や，部分切除を予定していて腫瘍が左副腎の頭側に存在す る症例では，出来る限り後腹膜後方到達法を第一選択としている。 当科で1999年11月までに施行した腹腔鏡下副腎摘除術120例（経腹 膜到達法70例，後腹膜到達法50例）の経験から，当科に扮ける到 達法の選択についてビデオにより解説する。

腹腔鏡下手術 副略摘除 後腹膜到達法

\section{V- 28 転移性副罢癌に対する後腹膜腔鏡下副紧摘 除術}

\section{長岡中央綜合病院泌尿器科1}

西山勉 ${ }^{1 ）}$ 照沼 正博1)

【目的】肺癌副腎転移2例に対し、後腹膜腔鏡下副腎摘除術を行っ たので供覧する。【方法】患者を側卧位にし、第12肋骨先端部皮 周に約 $2 \mathrm{~cm}$ の切開をおき、後腹膜腔に入った。用手ならびにバル ーンで操作腔を確保し、後腹膜腔鏡下操作を開始した。計4本の ポートで手術を行った。Gerota筋膜を切開し、腎上前方で腫場を 確認した。腫瘍を周囲から剥離、血管を結禁切断し、摘出した。 【結果】第1例は68歳男性で、肺癌術後、左副腎転移を認めたため、 後腹膜腔鏡下左副腎摘除術を行った。腫瘍の周囲への浸潤は軽度 であった。手術時間は197分で、出血は少量であった。摘出腫瑒 は2 $\times 1 \times 1 \mathrm{~cm}$ であった。第2例は72歳男性で、肺癌術後、右副腎転 移を認め、後腹膜腔鏡下右副腎摘除術を行った。腫場は周囲への 浸潤を認めたが、腫瘍の周囲からの剥離は比較的容易であった。 手術時間は191分で、出血は少量であった。摘出腫瘍は 4 × $3 \times 2 \mathrm{~cm}$ であった。2例とも術後経過は良好で、手術翌日には食事、歩行 を開始した。【結語】肺癌副腎転移に対する副腎摘除術は比較的 予後良好と報告されている。腫湯径が比較的小さく、周囲への浸 潤が比較的軽度と思われる肺癌副腎転移症例は後腹膜腔鏡下副腎 摘除術のよい適応と思われた。 